I University at Albany, State University of New York (SUNY),

Albany, NY, United States of America

rjacobs@albany.edu

https://orcid.org/0000-0002-I253-8102

Ronald N. Jacobs'

\title{
JEFFREY ALEXANDER AND THE DEVELOPMENT OF CULTURAL SOCIOLOGY
}

In this brief note I want to talk about Jeffrey Alexander's impact on cultural sociology and social theory. In particular, I want to focus on (I) the social dimensions of his theoretical practice, and (2) the impact of the ideas themselves. These comments are drawn not only from a close reading of his work, but also from a relationship that stretches nearly thirty years, beginning in Fall I990 when I joined the graduate program in Sociology at the University of California, Los Angeles.

One of Alexander's most significant impacts in global cultural sociology is social and performative, and grounded in a Durkheimian commitment to the importance of social solidarity. For Alexander, theory is not the product of a lone, creative, individual genius. It is a collaborative project. In Alexander's circle, collaboration works by creating a shared identity, a common project, and a set of rituals reinforcing the spirit of solidarity. This began early in his career as a faculty member at UCLA, and it intensified when he moved to Yale University as the Lillian Chavenson Saden Professor of Sociology.

Alexander's circle of collaborators have always had a common symbolic identity holding them together. In the early years, this was signified by the 'Culture Club,' which was a group of students, former students and visitors all working together to create a common language for doing a late-Durkheimian version of sociology that came to be known as cultural sociology. Cultural sociology was the sacred signifier; its meaning was crystallized through a semiotic opposition to the 'sociology of culture.' As Alexander's program for cultural so- 
ciology continued to develop during his time at Yale, he and Phil Smith rebranded the late-Durkheimian approach as the 'Strong Program in Cultural Sociology.' The Strong Program became a key reference point for meaning-centered sociologists around the world, allowing a wider and more diffuse network of sociologists to attach themselves to Alexander's version of cultural sociology.

As a Durkheimian, Alexander has always known that a shared symbolic system can more easily sustain a solidaristic community if it is reinforced by a regular cycle of rituals. While these rituals were informal during Alexander's UCLA years, they became much more strongly institutionalized with his move to Yale. The big event was the creation of the Center for Cultural Sociology in 2002. As the physical home for the Strong Program, the CCS established a weekly workshop in Cultural Sociology, with its own distinctive ritual practices of intensely critical-yet-supportive intellectual engagement. The CCS also became a pilgrimage site for the growing network of international scholars who were interested in the Strong Program, and who chose to spend sabbatical periods in New Haven, participating in the weekly workshop with other faculty, graduate students and visiting scholars. For my own graduate students, the CCS has indeed acted as a pilgrimage site; each visit there has left them more forcefully identified as Strong Program cultural sociologists, and more enthusiastically motivated to complete their work.

The final aspect of Alexander's intellectual practice that should be mentioned is his commitment to a spirit of supportive and critical dialogue. Ricoeur famously distinguished between a "hermeneutics of suspicion" and a "hermeneutics of faith." A hermeneutics of faith seeks to understand the text on its own terms, from the perspective of the author or speaker. A hermeneutics of faith reads with the author, believing that she has something important to say and working to draw out as fully as possible the key messages and contributions from her text. A hermeneutics of suspicion, in contrast, aims to unmask and expose the 'real' meaning of a text, by passing over its more self-evident meanings in order to discover the less visible (and usually less flattering) meanings that can be uncovered by reading against the author. A hermeneutics of suspicion aligns effectively with the agonistic nature of academic culture in general (and peer review in particular), but it is in clear tension with a more collaborative intellectual culture that seeks to uncover unrealized possibilities in a paper or presentation. In fact, as Ricoeur himself suggestion, a hermeneutics of suspicion is ultimately an impediment to real understanding, becoming a corrosive force that encourages the interpreter to see through everyone and everything (Scott-Baumann 2009). Alexander understands this limitation well. His intellectual engagement is deeply critical, and often combative, but it is not suspicious in the way that Ricoeur warned against.

Of course, Alexander's immense influence is not only a product of his social practice, but is also connected to the deep importance of the ideas con- 
tained in his published work. As the author of more than twenty books and hundreds of published articles, Alexander's corpus of work is immense. Over the last twenty years, at least, I think the contributions can be divided into two general theoretical areas: (I) theories of culture and meaning, and (2) theories of civil society and public life.

\section{THEORIES OF CULTURE AND MEANING}

In Alexander's approach to culture and meaning in social life, everything begins from the insistence that the world does not come to the analyst pre-interpreted. This was a phrase that has resonated with me for a long time. I know that he used it often in talks and conversations during the early years of the CCS, though I am not aware of its appearance in any published work. But I use it frequently with my own students, because I think that it captures the essential difference between the Strong Program and other approaches to culture in sociology.

To say that the world does not come pre-interpreted is to say that we cannot decide in advance which features of social life will be meaningful to individuals and groups. To be sure, the key categories of sociological analysis - race, class, gender, sexuality, nation, ethnicity, religion, and so forth - are important and meaningful, but we cannot decide in advance how they will be meaningful, or how they will be combined with other categories of meaningfulness. This is why Alexander insists on a Geertzian thick description, attempting to provide the best cultural map possible of the world of meaningfulness that actors are relying on to navigate through the world (Alexander, 2003).

Still, Alexander's thick description is explicitly a 'structural hermeneutics,' which explores specific meaning structures in order to deepen the cultural analysis and to understand how the different elements of meaning fit together. For today's cultural sociologists, Alexander's cultural theory functions much like Barthes's cultural theories did for an earlier generation, in the sense that they provide a set of conceptual tools from which cultural scholars can draw, depending on the kinds of data they are using and the kinds of questions they are asking.

Specifically, Alexander has developed extended theories and offered empirical exemplars for three distinct types of meaning structures. His theory of codes and narratives emphasizes deep meaning structures, which structure perceptions and evaluations for individuals and groups at a societal level. These kinds of meaning structures are durable and persist over long periods of time, and their existence allows individuals to act strategically and creatively. In order to identify these kinds of deep meaning structures, the analyst is instructed to think about the language-like properties of culture: emphasizing pattern over variation, stability over change, language over speech. Actors may speak differently, but the differences are only comprehensible because they are 
drawing from a common language, which can be mapped out by the cultural sociologist. His theory of cultural trauma focuses on social responses to crisis and injustice. It builds on the earlier work about codes and narratives, but here the main focus is on how carrier groups use the codes and narratives about good and evil to make demands for civil repair and social change. The main usefulness of the theory of cultural trauma, in my opinion at least, is that it provides an exceptionally nuanced cultural sociological approach for studying social movements and collective action. Finally, his theory of cultural performance takes a comprehensive look at the relationship between culture, agency, and the larger cultural environment of public cultural expression. This is a very flexible and sophisticated theory of cultural power, which Alexander has deployed with great effect in the analysis of political campaigns and which is a research tool that has been used with increasing frequency among sociologists interested in the strategic dimensions of politics and culture.

\section{THEORIES OF CIVIL SOCIETY AND PUBLIC LIFE}

Alexander's civil sphere theory is quickly becoming a global industry, because of his collaborative style that I described before and also because of the analytic power that the theory brings to a cultural sociology of public life. Alexander's starting point is fundamentally Durkheimian: specifically, that society is a moral thing that serves as a key anchor and reference point in the lives of individuals and groups. But Alexander takes a decidedly cultural approach to this starting point. In his analysis of the civil sphere, society itself is an object of interpretation, critique, and moral evaluation.

The civil sphere provides its own structure of analysis and interpretation. It has its own semiotic code, the discourse of civil society. It has a distinctive set of narratives, which center around the romantic (future-directed) possibility of justice and the tragic (past- and present-directed) reality of injustice. These tragic narratives get institutionalized in the collective memory of specific societies, as a series of cultural traumas that call for civil repair and periodic cycles of (re)interpretation. The demand for civil repair, which is central to Alexander's theory, provides a concrete and empirical way to think about how civil society operates simultaneously as the terrain of cultural and political struggle (i.e. the discursive space where the struggle takes place) and the object of that struggle (i.e. the shifting of public opinions and public narratives).

One of the key insights of Alexander's theory is that the civil sphere offers its own alternative moral metric for evaluating matters of common concern (Alexander, 2006). It is analytically autonomous from economic logics and political logics, and as such it offers a potential resource for getting people to think about a social issue in terms of a logic of justice rather than a logic of market rationality or political expediency. This is part of a competitive and agonistic process. Actors and groups have to put forth narratives and cultural 
performances that explain why an issue should be evaluated and regulated according to the civic logic, while competing actors put forth alternative narratives and performances in favor of a different logic.

The mechanics by which attempts at prioritizing the civil logic succeed and fail have significant consequences for the relative power that the civil sphere will have in particular societies and at particular points in time. In his newest work, which Alexander theorizes as the "societalization of social problems," he begins to pull apart the kinds of mechanisms by which this happens in the US. In a series of other collaborative projects - the Civil Sphere in Latin America, the Civil Sphere in East Asia, the Nordic Civil Sphere, the Civil Sphere and Radicalization - Alexander and his colleagues are beginning to identify the distinctive ways that these mechanisms operate in non-Western contexts. This work effectively combines the theoretical contributions in culture and civil society, and situates it within a global network of scholars committed to a common intellectual project. As with Alexander's other major projects, it is likely to produce consequential contributions in theory and empirical research, and it is likely to do so for a long time. Given the talk about the crisis of democracy and civil society in Europe, the US, and elsewhere, I expect that these works will be read widely. I know that I will continue to read the work with great interest, looking for ways to incorporate its insights into my own theoretical and empirical scholarship.

Received on I8/I0/20I8 | Approved on 6/2/20I9

Ronald N. Jacobs has a PhD in Sociology from UCLA. He is a professor at University at Albany (SUNY) and one of the editors of the American Journal of Cultural Sociology. His publications include Race, media, and the crisis of civil society: From Watts to Rodney King (2000) and, with Jeffrey Alexander and Philip Smith (eds.), The Oxford Handbook of Cultural Sociology (2012). 


\section{BIBLIOGRAPHY}

Alexander, Jeffrey C. (2006). The civil sphere. Oxford: Oxford University Press.

Alexander, Jeffrey C. (2003). The meanings of social life: a cultural sociology. Oxford: Oxford University Press.

Scott-Baumann, Alison. (2009). Ricœur and the Hermeneutics of Suspicion. London: Continuum Publishing Group. 
Palavras-chave

Jeffrey Alexander; sociologia cultural; esfera civil; teoria sociológica; hermenêutica da fé.

Keywords

Jeffrey Alexander; cultural sociology; civil sphere; sociological theory; hermeneutics of faith.

\section{JEFFREY ALEXANDER E O DESENVOLVIMENTO DA} SOCIOLOGIA CULTURAL

\section{Resumo}

O trabalho de Alexander tem produzido um impacto decisivo na sociologia cultural e no desenvolvimento da teoria social de um modo geral. Sua produção em sociologia cultural oferece uma ampla e útil caixa de ferramentas para os sociólogos interessados em pesquisas empíricas sobre as relações entre os significados e a sociedade. Sua teoria da esfera civil fornece um modelo para os pesquisadores interessados em estudar os processos pelos quais a própria sociedade se torna um objeto de interpretação e de avaliação. Todas essas contribuições intelectuais têm se apoiado em um estilo generoso de prática teórica, que combina solidariedade, ritual e um compromisso com uma "hermenêutica da fé" (nos termos de Ricœur).

\section{JEFFREY ALEXANDER AND THE DEVELOPMENT OF CULTURAL SOCIOLOGY}

\section{Abstract}

Alexander's work has had a major impact on cultural sociology and the development of sociological theory more generally. His work in cultural sociology provides a large and useful toolkit for sociologists interested in doing empirical work on meaning and society. His theory of the civil sphere provides a template for scholars interested in studying the processes by which society itself become an object of interpretation and evaluation. All of these intellectual contributions have been supported by a generous style of theoretical practice, which combines solidarity, ritual, and a commitment to a "hermeneutics of faith". 